\section{Effect of Fluoride Concentration on Reduction of Enamel Demineralization According to the Cariogenic Challenge}

Mayara dos Santos Noronha, Dayse Andrade Romão, Jaime Aparecido Cury, Cínthia Pereira Machado Tabchoury
Piracicaba Dental School, UNICAMP

- Universidade Estadual de

Campinas, Piracicaba, SP, Brazil

Correspondence: Prof. Dr. Cínthia

Pereira Machado Tabchoury,

Av. Limeira, 901, 13.414-903

Piracicaba, SP, Brasil. Tel. +55-

19-2106-5304/5303. e-mail:

cinthia@fop.unicamp.br

\begin{abstract}
Fluoride present in toothpaste at 1,100 $\mu \mathrm{g} / \mathrm{g}$ is considered effective on caries control. However, under high cariogenic challenge due to increasing sugar exposure, higher fluoride concentration $(5,000 \mu \mathrm{g} / \mathrm{g})$ could be necessary to compensate the unbalance on caries process. This was tested in a $\mathrm{pH}$-cycling regimen, which evaluated the effect of fluoride concentration relative to toothpaste on reduction of enamel demineralization under conditions of two levels of cariogenic challenge. Enamel slabs $(n=20)$ were subjected to two $\mathrm{pH}$-cycling regimens, simulating $8 \mathrm{x}$ and $16 \mathrm{x} /$ day sugar exposure and were treated with solutions containing: 0 (no fluoride), 275 or $1,250 \mu \mathrm{g} \mathrm{F} / \mathrm{mL}$, resulting in 6 treatment groups: 4-h/0-F; 8-h/0-F; 4-h/275-F; 8-h/275-F; 4-h/1,250-F and 8-h/1,250-F. The 275 and $1,250 \mu \mathrm{g} F / \mathrm{mL}$ concentrations simulate mouth salivary dilution when 1,100 and 5,000 $\mu \mathrm{g} / \mathrm{g}$ toothpastes are used. Enamel demineralization was assessed by surface $(\% \mathrm{SHL})$ and cross-sectional hardness. Fluoride taken up by enamel was also evaluated. Data were analyzed by ANOVA one-way and Tukey's test. The treatment with 1,250 $\mu \mathrm{g}$ $\mathrm{F} / \mathrm{mL}$ significantly reduced $\% \mathrm{SHL}$ compared with $275 \mu \mathrm{g} \mathrm{F} / \mathrm{mL}(\mathrm{p}<0.05)$, irrespective the level of cariogenic challenge (4-h/1,250-F vs. 4-h/275-F and $8-\mathrm{h} / 1,250-\mathrm{F}$ vs $8-\mathrm{h} / 275-\mathrm{F}$ comparisons, respectively). These data were supported by fluoride concentration found in enamel. These findings suggest that higher fluoride concentrations could partly compensate the greater caries risk under higher cariogenic challenge due to increasing sugar exposure.
\end{abstract}

Key Words: dental caries, dental enamel, fluorides, tooth demineralization, toothpaste.

\section{Introduction}

Dental caries is a biofilm and sugar-dependent disease that can lead to a progressive loss of tooth mineral (1). Biofilm accumulation is a necessary but not a sufficient factor for the development of caries lesions, while the frequent exposure to sugars is the determinant factor (2). Indeed, sugar has been considered the only cause of caries (3).

One way to try to balance the detrimental effect of sugar on caries is the fluoride. Working on caries process, reducing demineralization and enhancing remineralization, fluoride is clearly effective to slow down the progression of caries lesions but it does not avoid the disease $(4,5)$. Epidemiological surveys have shown in children and adults the effect of sugars on caries and the limited effect of fluoride on its control $(6,7)$.

The relationship between sugar exposure and fluoride effect on caries has been evaluated in well-controlled in situ studies (8-11). Duggal et al. (9) and Ccahuana-Vasquez et al. (10) showed that if the daily frequency of sugar were not above 7 to 8 times/day, fluoride from 1,100 $\mu \mathrm{g} / \mathrm{g}$ toothpaste would be effective to control enamel demineralization. Cury et al. (11) evaluated the relationship between fluoride concentration in toothpaste and sugar exposure on human enamel demineralization. They showed that a toothpaste containing 1,100 $\mu \mathrm{g} \mathrm{F/g}$ was more effective than one with half this concentration to slow down caries progression when sugar exposure was above $2 x /$ day.

Considering that it is based on evidence that sugar exposure is the cause of caries (3) and that the fluoride effect on enamel caries is concentration-dependent $(12,13)$, it is plausible to hypothesize that an increase in the concentration of fluoride could compensate for caries increment caused by increasing sugar exposure. To test this hypothesis the effect of fluoride concentration in toothpaste on the reduction of enamel demineralization, using a $\mathrm{pH}$-cycling model and simulating conditions of higher cariogenic challenge (sugar exposure of $8 x$ and $16 x /$ day), was evaluated.

\section{Material and Methods Experimental Design}

An in vitro experimental, randomized and blind study was conducted to evaluate the effect of fluoride concentration on the reduction of enamel demineralization under conditions of higher cariogenic challenges. Enamel slabs obtained from bovine incisor teeth and selected according to surface hardness $(\mathrm{SH})$, were subjected to 
$\mathrm{pH}$-cycling regimens, simulating two different levels of cariogenic challenge (4- and 8-h immersion in demineralizing solution, simulating respectively 8 and $16 x /$ day sugar exposure). The slabs ( $n=20 /$ group) were exposed to the levels of cariogenic challenge described above and subjected $2 x /$ day to treatments with solutions containing: 0 (negative control), 275 or 1,250 $\mu \mathrm{g} \mathrm{F/mL}$. This resulted in 6 treatment groups: 4-h/0-F; 8-h/0-F; 4-h/275-F; 8-h/275-F; 4-h/1,250-F and 8-h/1,250-F. The $\mathrm{pH}$-cycling regimen lasted 8 days and, at the end of the $5^{\text {th }}$ day, de- and remineralizing solutions were replaced by fresh ones. At the end of the experiment, percentage of surface hardness loss $(\% \mathrm{SHL})$, carious lesion area $(\Delta \mathrm{S})$ and concentration of $\mathrm{F}$ in enamel were assessed in the slabs. In de- and remineralizing solutions collected at the $5^{\text {th }}$ and last day of $\mathrm{pH}$ cycling, fluoride concentration was determined. The null hypothesis tested was that higher fluoride concentration would compensate a greater risk to demineralization by a higher cariogenic challenge. The data were analyzed by one-way ANOVA and Tukey's test. Significance level was set at 5\%.

\section{Enamel Slabs Preparation}

Bovine incisor teeth, stored in 2\% formaldehyde solution for at least 30 days (14), were used to prepare flattened and polished enamel slabs $(4 \times 4 \times 2 \mathrm{~mm})$. The baseline surface hardness ( $\mathrm{SH}$ ) of the dental slabs was determined by a hardness tester (Future-Tech Corp., Tokyo, Japan), with Knoop diamond under a $50 \mathrm{~g}$ load for $10 \mathrm{~s}$. One hundred and twenty enamel slabs with baseline SH of $332.3 \pm 14.9 \mathrm{~kg} / \mathrm{mm}^{2}$ were selected. These slabs were randomly distributed into six groups of treatment $(n=20)$ described in the experimental design section. A piece of adhesive paper $(2 \times 4 \mathrm{~mm})$ was placed over the polished central surface of the enamel slabs, which were then coated with acid-resistant varnish (nail polish, Risquéø, São Paulo, SP, Brazil). After drying, the adhesive paper was removed to expose a surface area of $8.0 \mathrm{~mm}^{2}$ to the treatments.

\section{Demineralizing $\mathrm{pH}$-Cycling Regimen and Treatments}

The slabs were subjected to two conditions of cariogenic challenge, using the validated $\mathrm{pH}$-cycling model described by Queiroz et al. (15). They were daily immersed during 4 $\mathrm{h}$ or $8 \mathrm{~h}$ in demineralizing solutions, representing sugar exposures of $8 x$ and $16 x /$ day, respectively (considering that biofilm $\mathrm{pH}$ remains 30 min below the critical value for enamel demineralization every time that sugar is ingested). Both $\mathrm{pH}$-cycling regimens lasted for 8 days. The slabs were individually immersed in a demineralizing solution containing $0.1 \mathrm{M}$ acetate buffer, $\mathrm{pH} 5.0,1.28 \mathrm{mM}$ $\mathrm{Ca}, 0.74 \mathrm{mM} \mathrm{P}$ and $0.03 \mu \mathrm{g} \mathrm{F} / \mathrm{mL}$ (16) for $4 \mathrm{~h}$ and for $8 \mathrm{~h}$ at $37{ }^{\circ} \mathrm{C}$. For the remainder of the daily cycle, slabs were individually immersed in remineralizing solution (Tris buffer 20 mM, pH 7.0, 1.5 mM Ca, 0.9 mM P, $150 \mathrm{mM} \mathrm{KCl}, 0.05$ $\mu \mathrm{g} \mathrm{F} / \mathrm{mL}$ ). The duration of immersion in the demineralizing solution was pre-determined and standardized in a pilot study to create two levels of cariogenic challenge. The volume of demineralizing and remineralizing solution per area of exposed enamel surface was 6.25 and $3.12 \mathrm{~mL} / \mathrm{mm}^{2}$, respectively. Twice a day (before and after the immersion in demineralizing solution), the slabs were washed with purified water and exposed to treatments with purified water (negative control), 275 or $1,250 \mu \mathrm{g} \mathrm{F} / \mathrm{mL}$ (from $\mathrm{NaF}$ ) under agitation in a shaker for $5 \mathrm{~min}$. These fluoride concentrations match the dilution ( $1: 3 \mathrm{w} / \mathrm{w})$ that occurs in the oral cavity (17) with toothpastes containing 1,100 and 5,000 $\mu \mathrm{g} \mathrm{F/g}$, respectively. After the fifth day of $\mathrm{pH}$ cycling, de- and remineralizing solutions were replaced by fresh ones. At the end of the 8th cycle, the slabs were immersed in remineralizing solution for additional $24 \mathrm{~h}$ before analysis (18).

\section{Enamel Demineralization Assessment}

Surface hardness (SH) of the 20 slabs of each treatment group was measured before and after the $\mathrm{pH}$ cycling. The mean values from the three indentations, spaced $100 \mu \mathrm{m}$ from each other, and the baseline values were averaged and the percentage of surface hardness loss $[\% \mathrm{SHL}=$ 100 (SH after pH cycling - baseline SH)/baseline SH] was calculated. Subsequently, 15 enamel slabs from each group were randomly selected and longitudinally sectioned through the center for cross sectional hardness (CSH) determination. Three rows of 13 indentations each were made at 10 up to $60 \mu \mathrm{m}$ ( $10 \mu \mathrm{m}$ between each indentation) and from 60 to $200 \mu \mathrm{m}$ ( $20 \mu \mathrm{m}$ between each other) depths from the outer surface of the enamel slabs. The mean values for the 3 measuring points at each distance from the surface was then averaged and expressed as Knoop hardness number $\left(\mathrm{kg} / \mathrm{mm}^{2}\right)$. The area of carious lesion $(\Delta \mathrm{S})$ was calculated by difference between the area under the curve $\left(\mathrm{kg} / \mathrm{mm}^{2} \times \mu \mathrm{m}\right)$ of the sound enamel and the area of the demineralized one (11). For these analysis, a hardness tester (Future-Tech FM Corp., Tokyo, Japan) was used with a FM-ARS software, and a Knoop indenter with a $50 \mathrm{~g}$ for $10 \mathrm{~s}$ and $25 \mathrm{~g}$ for $5 \mathrm{~s}$, respectively, for SH and CSH. SH and $\mathrm{CSH}$ were used as indicators of enamel demineralization because they are considered reliable methodologies to estimate enamel demineralization $(19,20)$. There is also an association between enamel $\mathrm{SH}$ and $\mathrm{CSH}$ with white spot caries lesions (21).

\section{Fluoride Concentration in Enamel}

Total fluoride formed in enamel was determined in the 5 slabs from each group not used for $\mathrm{CSH}$ assessment. Two 
enamel layers were sequentially removed by immersion of each slab in $0.4 \mathrm{~mL}$ of $0.5 \mathrm{M} \mathrm{HCl}$ for 15 and $30 \mathrm{~s}$ under agitation. The extract containing the dissolved enamel layer was buffered with the same volume of TISAB II, $\mathrm{pH}$ 5.0, modified with $20 \mathrm{~g}$ of $\mathrm{NaOH} / \mathrm{L}$ (22). Fluoride was determined using an ion-selective electrode (Orion 96-09; Orion Research Inc., Boston, MA, USA) and an ion analyzer (Orion EA-940; Orion), previously calibrated with standard fluoridated solutions ranging from 0.031 to $8 \mu \mathrm{g} \mathrm{F} / \mathrm{mL}$. The concentration of fluoride in each layer of removed enamel was summed up and the results were expressed in $\mu \mathrm{g} \mathrm{F} / \mathrm{cm}^{2}$ (23).

\section{Fluoride Determination in De- and Remineralizing Solutions}

The concentrations of fluoride were evaluated in de- and remineralizing solutions after the fifth and last day of $\mathrm{pH}$-cycling regimen. For fluoride analysis, an ionselective electrode (Orion 96-09; Orion) and an ion analyzer (Orion EA-940, Orion), previously calibrated with standard fluoridated solutions ranging from 0.023 to $0.364 \mu \mathrm{g} \mathrm{F}$ $\mathrm{mL}$, were used.

\section{Statistical Analysis}

The assumptions of equality of variances and normal distribution of errors were checked by Shapiro-Wilks test for all the tested response variables (24) and the data were analyzed by ANOVA one-way and Tukey's test. The significance level was $5 \%$. The analyses were performed using the statistical software R 3.0.1 (www.r-project.org).

\section{Results}

Table 1 shows that the $\mathrm{pH}$-cycling model used was able to simulate two different levels of cariogenic challenge, because the treatment group 8-h/0-F presented higher

Table 1. Means and SD of percentage of surface hardness loss (\%SHL), area of carious lesion $\left(\Delta \mathrm{S} ; \mathrm{Kg} / \mathrm{mm}^{2} \mathrm{x} \mu \mathrm{m}\right)$ and fluoride in enamel $\left(\mu \mathrm{g} F / \mathrm{cm}^{2}\right)$, according to the level of cariogenic challenge (4- or 8-h in de- solution) and treatments with fluoride (0 to $1,250 \mu \mathrm{g} \mathrm{F} / \mathrm{mL}$ )

\begin{tabular}{lccc}
\hline $\begin{array}{l}\text { Cariogenic challenge/ } \\
\text { Fluoride treatment }\end{array}$ & $\begin{array}{c}\% \mathrm{SHL} \\
(\mathrm{n}=20)\end{array}$ & $\Delta \mathrm{S}(\mathrm{n}=15)$ & $\begin{array}{c}\text { Fluoride in } \\
\text { enamel }(\mathrm{n}=5)\end{array}$ \\
\hline 4-h/0-F & $51.9 \pm 7.3 \mathrm{a}$ & $5259.2 \pm 1872.7 \mathrm{a}$ & $1.5 \pm 0.2 \mathrm{a}$ \\
8-h/0-F & $80.2 \pm 10.2 \mathrm{~b}$ & $9246.7 \pm 3244.9 \mathrm{~b}$ & $1.4 \pm 0.4 \mathrm{a}$ \\
4-h/275-F & $30.0 \pm 7.2 \mathrm{c}$ & $3098.9 \pm 1646.1 \mathrm{c}$ & $5.2 \pm 1.9 \mathrm{a}$ \\
8-h/275-F & $38.6 \pm 6.5 \mathrm{~d}$ & $3665.1 \pm 997.9 \mathrm{ac}$ & $10.4 \pm 2.1 \mathrm{~b}$ \\
$4-\mathrm{h} / 1,250-\mathrm{F}$ & $21.7 \pm 6.1 \mathrm{e}$ & $2501.8 \pm 1347.8 \mathrm{c}$ & $5.8 \pm 3.1 \mathrm{a}$ \\
8-h/1,250-F & $29.7 \pm 5.4 \mathrm{c}$ & $2545.1 \pm 1579.7 \mathrm{c}$ & $16.3 \pm 3.8 \mathrm{c}$ \\
\hline
\end{tabular}

Means followed by distinct lowercase letters in columns differ statistically at $\mathrm{p}<0.05$. demineralization in terms of \%SHL and $\Delta \mathrm{S}$ than $4-\mathrm{h} / 0-\mathrm{F}$ $(p<0.05)$. Regarding the effect of fluoride concentration, the treatment with $1,250 \mu \mathrm{g} \mathrm{F} / \mathrm{mL}$ significantly reduced $\%$ SHL compared with $275 \mu \mathrm{g} \mathrm{F} / \mathrm{mL}(\mathrm{p}<0.05)$, irrespective the level of cariogenic challenge (4-h/1,250-Fvs. 4-h/275-F and $8-\mathrm{h} / 1,250-\mathrm{F}$ vs $8-\mathrm{h} / 275-\mathrm{F}$ comparisons, respectively), but for $\Delta S$ the differences were not significant ( $p>0.05)$.

Statistically higher $F$ concentration in enamel $(p<0.05)$ was found in the slabs treated with $8-\mathrm{h} / 275-\mathrm{F}$ and $8-\mathrm{h} / 1,250-\mathrm{F}$ in comparison with those in the negative control group (Table 1).

De- and remineralizing solutions showed significantly higher fluoride concentrations in the groups $4-\mathrm{h} / 1250-\mathrm{F}$ and $8-h / 1250-F(p<0.05)$ than the negative control and the groups $4-\mathrm{h} / 275-\mathrm{F}$ and $8-\mathrm{h} / 275-\mathrm{F}$, either in the solutions collected on the $5^{\text {th }}$ or the last day of the $\mathrm{pH}$ cycling.

\section{Discussion}

The $\mathrm{pH}$-cycling model used was adapted from Queiroz et al. (15) and allowed the simulation of two different levels of cariogenic challenge. Considering both \%SHL and $\Delta \mathrm{S}$ (Table 1), 8-h immersion in demineralizing solution significantly resulted in higher mineral loss than immersion for $4 \mathrm{~h}$. The duration of immersion of the enamel slabs in the demineralizing solution was defined in a pilot study and represents the exposure to cariogenic challenges at two different levels, simulating in vivo periods of lowering of biofilm $\mathrm{pH}$ (immersion in demineralizing solution) and return to baseline values (immersion in remineralizing solution). For practical reasons, only one period of demineralization, representing all episodes, was conducted in the $\mathrm{pH}$-cycling regimen per day. In vivo, every time sugar is ingested, there is a $\mathrm{pH}$ drop in dental biofilm, falling below the critical $\mathrm{pH}$ for enamel, which may last about 30 min (25). Thus, two clinical conditions were simulated in the present study: daily sugar consumption of 8 times (4-h period) and of 16 times (8-h period) for a higher cariogenic challenge.

The effect of 1,250- $F$ in $8-h$ challenge was equivalent to that of $275-\mathrm{F}$ in $4-\mathrm{h}$ challenge, since both groups did not differ statistically with regards to \%SHL ( $p>0.05$ ). In higher cariogenic challenge, a greater fluoride concentration seemed to be necessary to compensate the high risk of caries and decreased $\% \mathrm{SHL}$, as could be seen in this study. The effect of high fluoride concentration, which simulates the use of high $F$ toothpaste, was more pronounced in reducing mineral loss under conditions of higher cariogenic challenges. These findings are in agreement with a clinical study in which the effect of fluoride in higher concentrations was evaluated in high caries risk 
adolescents, who do not use toothpaste regularly (26). The use of higher concentrations of fluoride in dentifrice $(5,000 \mu \mathrm{g} \mathrm{F} / \mathrm{g})$ produced lower progression of caries when compared with the 1,450 $\mu \mathrm{g} \mathrm{F/g}$ after 2 years, according to clinical and radiographic examinations. Therefore, one must consider changes in exposure to fluoride based on the individual risk of caries and the present findings suggest that high fluoride toothpaste would be required for higher cariogenic challenges in order to achieve the same effect as a conventional toothpaste at the initiation of mineral Ioss. Nevertheless, studies with toothpastes on the market are necessary to validate this $\mathrm{pH}$-cycling regimen of high cariogenic challenge.

Although the effect of fluoride on reduction of demineralization has been found in both treatment groups according to $\% \mathrm{SHL}$ and $\Delta \mathrm{S}$ values (Table 1 ), the findings of this study showed that the magnitude of its effect at the same concentration seems to be different, depending on the cariogenic challenge. Regarding \%SHL, treatment with $275-\mathrm{F}$ resulted in $43 \%$ and $52 \%$ inhibition, respectively, for the 4-h and 8-h cariogenic challenge, whereas in the treatment with high $\mathrm{F}$ concentration $(1,250-\mathrm{F})$ an inhibition of $58 \%$ and $63 \%$ was found. $\Delta S$ data corroborate these findings: inhibition of $41 \%$ and $60 \%$ for treatment

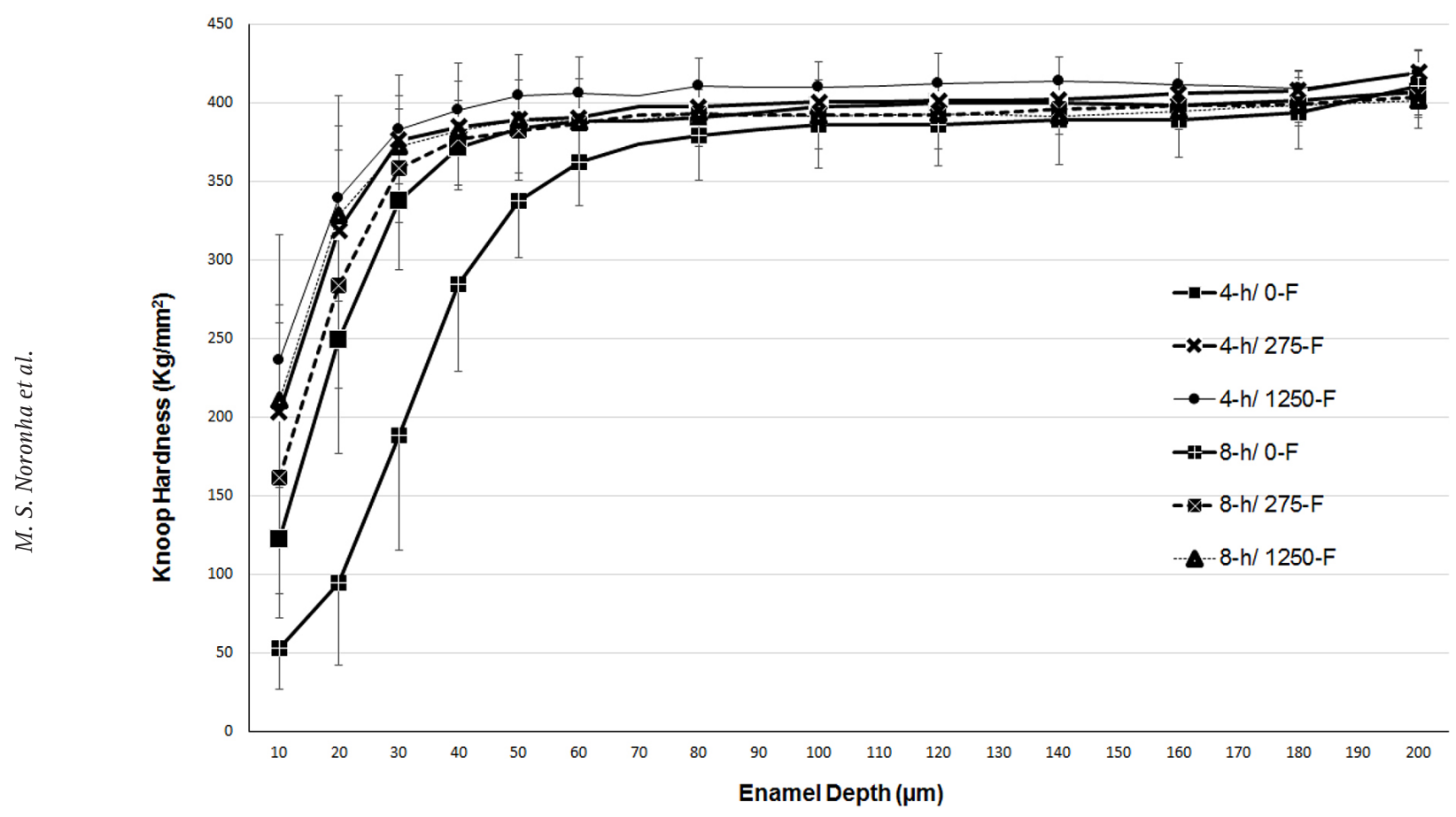

Figure 1. Enamel hardness $\left(\mathrm{kg} / \mathrm{mm}^{2}\right)$ according to the distance $(\mu \mathrm{m})$ from the surface and the treatment used ( $\mathrm{n}=15$ per group). Bars denote standard deviations (SD).

Table 2. Means and SD of fluoride $(\mu \mathrm{g} / \mathrm{mL})$ concentration in de- and remineralizing solutions after the $5^{\text {th }}$ and last day of $\mathrm{pH}$ cycling, according to the level of cariogenic challenge (4- or 8-h in de- solution) and treatments with fluoride (0 to $1,250 \mu \mathrm{g} F / \mathrm{mL})(\mathrm{n}=20)$

\begin{tabular}{lcccc}
\hline $\begin{array}{l}\text { Cariogenic challenge/ } \\
\text { Fluoride treatment }\end{array}$ & $\begin{array}{c}\text { F Demineralizing Solution } \\
\left(5^{\text {th }} \text { day }\right)\end{array}$ & $\begin{array}{c}\text { F Demineralizing Solution } \\
\text { (last day) }\end{array}$ & $\begin{array}{c}\text { F Remineralizing Solution } \\
\left.\text { (5 } 5^{\text {th }} \text { day }\right)\end{array}$ & $\begin{array}{c}\text { F Remineralizing Solution } \\
\text { (last day) }\end{array}$ \\
\hline $4-\mathrm{h} / 0-\mathrm{F}$ & $0.032 \pm 0.002 \mathrm{a}$ & $0.030 \pm 0.001 \mathrm{a}$ & $0.036 \pm 0.009 \mathrm{a}$ & $0.039 \pm 0.002 \mathrm{a}$ \\
$8-\mathrm{h} / 0-\mathrm{F}$ & $0.030 \pm 0.004 \mathrm{a}$ & $0.030 \pm 0.001 \mathrm{a}$ & $0.040 \pm 0.002 \mathrm{a}$ & $0.041 \pm 0.001 \mathrm{~b}$ \\
$4-\mathrm{h} / 275-\mathrm{F}$ & $0.037 \pm 0.002 \mathrm{~b}$ & $0.033 \pm 0.001 \mathrm{~b}$ & $0.052 \pm 0.004 \mathrm{~b}$ & $0.047 \pm 0.002 \mathrm{c}$ \\
$8-\mathrm{h} / 275-\mathrm{F}$ & $0.039 \pm 0.003 \mathrm{~b}$ & $0.035 \pm 0.002 \mathrm{c}$ & $0.058 \pm 0.005 \mathrm{~b}$ & $0.051 \pm 0.005 \mathrm{~d}$ \\
$4-\mathrm{h} / 1,250-\mathrm{F}$ & $0.046 \pm 0.007 \mathrm{c}$ & $0.049 \pm 0.006 \mathrm{~d}$ & $0.066 \pm 0.008 \mathrm{c}$ & $0.067 \pm 0.012 \mathrm{e}$ \\
$8-\mathrm{h} / 1,250-\mathrm{F}$ & $0.049 \pm 0.004 \mathrm{c}$ & $0.043 \pm 0.003 \mathrm{e}$ & $0.079 \pm 0.007 \mathrm{~d}$ & $0.062 \pm 0.005 \mathrm{e}$ \\
\hline
\end{tabular}

Means followed by distinct lowercase letters in columns differ statistically at $\mathrm{p}<0.05$. Initial $\mathrm{F}$ concentration (fresh solution). Demineralizing solution: $0.032 \mu \mathrm{g} \mathrm{F} / \mathrm{mL}$; Remineralizing Solution: $0.047 \mu \mathrm{g}$ F/mL. 
with 275-F, respectively, for the 4-h and 8-h cariogenic challenge, while $52 \%$ and $72 \%$ were found for the treatment with 1,250- $F$ concentration. Considering caries lesions as indicator of caries risk, the data are in agreement with clinical trials showing that the anti-caries effect of fluoride from toothpaste increased with higher baseline levels of D(M)FS (27).

The profile of hardness according to the distance from the surface (Fig. 1) confirms the \%SHL and $\Delta \mathrm{S}$ data, showing that the $\mathrm{pH}$-regimens of 4-h and 8-h in demineralizing solution were able to produce caries lesions of different depths; lesions about 50- and 80- $\mu \mathrm{m}$ deep, respectively, were found. It was previously shown (15) by polarized microscopy that the lesions produced by the daily $4-h$ immersion in demineralizing solution were subsurface without erosion on the surface. The original model was modified, increasing this time for 8-h to simulate a greater cariogenic challenge. Even in this condition, no erosion was found on the surface, because it was possible to accurately measure the indentations made on the enamel surface.

The results of \%SHL and $\Delta \mathrm{S}$ are also confirmed by fluoride concentration in enamel (Table 2), which is an indicator of fluoride effect in de- and remineralization (28). Decreased mineral loss observed either for \%SHL or $\Delta S$ in groups treated with fluoridated solutions, especially those exposed to high cariogenic challenge, are supported by the highest fluoride incorporation in enamel found in these groups. Such data are consistent with the in vitro findings of Velo et al. (29), Fernández et al. (28) and in situ results obtained by Cury et al. (11), who showed that under high exposure to sugars, more $F$ in enamel was observed and with greater fluoride uptake as function of fluoride concentration. During the demineralization, which was conducted at two different levels in the present study, apatitic minerals were dissolved, while minerals containing fluoride, like fluorapatite, were incorporated into enamel. Thus, mineral loss in enamel was reduced, which was found in groups treated with fluoride, especially the slabs treated with high fluoride concentration, which also resulted in an enrichment of enamel by fluoride.

Moreover, higher fluoride concentrations were found in de- and remineralizing solutions in groups treated with $1,250 \mu \mathrm{g} \mathrm{F} / \mathrm{mL}$ than in the other groups $(p<0.05)$. These results are supported by the reactivity of fluoride present in the treatment solution with enamel, forming fluoride products that are released into de- and remineralizing solutions. In addition, these findings may support the data found in $\mathrm{F}$ concentration in enamel, \% $\% \mathrm{SL}$ and $\Delta \mathrm{S}$ in treatments with different fluoride concentrations, since more fluoride was found in 1,250-F groups and more fluoride was available to interfere in de- and remineralizing processes.
In conclusion, the outcomes of this study suggest that the effect of fluoride was influenced by the level of cariogenic challenge and higher concentrations of fluoride showed a greater effect on the reduction of the initiation of mineral loss in situations of higher cariogenic challenge. The in vitro findings could indicate that under higher cariogenic challenge due to increasing sugar exposure, higher fluoride concentrations could partially compensate the higher caries risk.

\section{Resumo}

0 fluoreto presente em dentifrícios de 1,100 $\mu \mathrm{g} / \mathrm{g}$ é considerado efetivo no controle de cárie dental. No entanto, sob alto desafio cariogênico devido ao aumento da exposição ao açúcar, maior concentração de fluoreto $(5.000 \mu \mathrm{g} / \mathrm{g})$ poderia ser necessária para compensar o desequilibrio no processo de cárie. Isso foi testado em um modelo de ciclagens de $\mathrm{pH}$, que avaliou o efeito da concentração do fluoreto, relacionada ao dentifricio, na redução da desmineralização do esmalte dental sob condição de dois níveis de desafio cariogênico. Blocos de esmalte $(n=20)$ foram submetidos a dois regimes de ciclagens de $\mathrm{pH}$, simulando 8 e 16 exposições diárias ao açúcar, e foram tratados com soluções contendo: 0 (sem flúor), 275 ou $1.250 \mu \mathrm{g} \mathrm{F} / \mathrm{mL}$, resultando em 6 grupos de tratamento: 4-h/0-F; 8-h/0-F; 4-h/275-F; 8-h/275-F; 4-h/1.250-F e 8-h/1.250-F. As concentrações de 275 e $1.250 \mu \mathrm{g} / \mathrm{mL}$ simularam uma diluição salivar na cavidade bucal quando dentifrícios de 1100 e $5000 \mu \mathrm{g} F / g$ são usados. A desmineralização do esmalte foi avaliada na superfície (\%PDS) e dureza em corte. Fluoreto incorporado pelo esmalte também foi determinado. Os dados foram analisados por Análise de Variância e teste de Tukey. 0 tratamento com $1.250 \mu \mathrm{g} \mathrm{F/mL}$ reduziu significativamente \%PDS comparado ao de $275 \mu \mathrm{g} \mathrm{F} / \mathrm{mL}(\mathrm{p}<0,05)$, independente do nivel do desafio cariogênico (comparações 4-h/1,250-F x 4-h/275-F e 8-h/1,250-F x 8-h/275-F, respectivamente). Esses resultados foram suportados pela concentração de fluoreto encontrada no esmalte. Os resultados sugerem que maior concentração de fluoreto pode parcialmente compensar um maior risco de cárie sob um maior desafio cariogênico provocado pelo aumento de exposição ao açúcar.

\section{Acknowledgements}

We thank Waldomiro Vieira Filho for the laboratorial assistance, FAPEAM (Fundação de Amparo à Pesquisa do Estado do Amazonas) for the scholarship (Grant \#03/2013) to the first author and FAPESP for the financial support (Grant \#2013/15251-9). All authors have made substantive contributions to this study and/or manuscript, and all have reviewed the final version of the manuscript prior to its submission. Conceived and designed the experiments: CPMT, JAC. Performed the experiments: DAR, MSN. Analyzed the data: CPMT, JAC, MSN. Wrote the paper: CPMT, DAR, JAC, MSN.

\section{References}

1. Fejerskov 0. Changing paradigms in concepts on dental caries: consequences for oral health care. Caries Res 2004;38:182-191.

2. Tenuta LM, Cury JA. Fluoride: its role in dentistry. Braz Oral Res 2010;24(Suppl 1):9-17.

3. Sheiham A, James WP. Diet and dental caries: the pivotal role of free sugars reemphasized. J Dent Res 2015;94:1341-1347.

4. Fejerskov 0, Cury JA, Tenuta LMA, Marinho VC. Fluorides in caries control. In: Dental Caries: The disease and its clinical management. Fejerskov 0, Kidd E (Org.). 3rd ed. Oxford: Blackwell \& Munksgaard; 2015. p. 20-47.

5. Cury JA, de Oliveira BH, Dos Santos AP, Tenuta LM. Are fluoride releasing dental materials clinically effective on caries control? Dent Mater 2016;32:323-333.

6. Bernabé E, Vehkalahti MM, Sheiham A, Lundqvist A, Suominen AL. The 
shape of the dose-response relationship between sugars and caries in adults. J Dent Res 2016;95:167-172.

7. Peres MA, Sheiham A, Liu P, Demarco FF, Silva AE, Assunção MC, et al.. Sugar consumption and changes in dental caries from childhood to adolescence. J Dent Res 2016;95:388-394.

8. Cury JA, Francisco SB, Del Bel Cury AA, Tabchoury CP. In situ study of sucrose exposure, mutans streptococci in dental plaque and dental caries. Braz Dent J 2001;12:101-104.

9. Duggal MS, Toumba KJ, Amaechi BT, Kowash MB, Higham SM. Enamel demineralization in situ with various frequencies of carbohydrate consumption with and without fluoride toothpaste. J Dent Res 2001;80:1721-1724.

10. Ccahuana-Vásquez RA, Tabchoury CP, Tenuta LM, Del Bel Cury AA, Vale GC, Cury JA. Effect of frequency of sucrose exposure on dental biofilm composition and enamel demineralization in the presence of fluoride. Caries Res 2007:41:9-15.

11. Cury JA, do Amaral RC, Tenuta LM, Del Bel Cury AA, Tabchoury CP. Low-fluoride toothpaste and deciduous enamel demineralization under biofilm accumulation and sucrose exposure. Eur J Oral Sci 2010;118:370-375.

12. Walsh $\mathrm{T}$, Worthington HV, Glenny AM, Appelbe P, Marinho VC, Shi $X$. Fluoride toothpastes of different concentrations for preventing dental caries in children and adolescents. Cochrane Database Syst Rev 2010:CD007868.

13. Dos Santos AP, Nadanovsky $P$, de Oliveira BH. A systematic review and meta-analysis of the effects of fluoride toothpastes on the prevention of dental caries in the primary dentition of preschool children. Community Dent Oral Epidemiol 2013;41:1-12.

14. White DJ. Reactivity of fluoride dentifrices with artificial caries I. Effects on early lesions: F uptake, surface hardening and remineralization. Caries Res 1987;21:126-140.

15. Queiroz CS, Hara AT, Paes Leme AF, Cury JA. pH-cycling models to evaluate the effect of low fluoride dentifrice on enamel de- and remineralization. Braz Dent J 2008;19:21-27.

16. Moi GP, Tenuta LM, Cury JA. Anticaries potential of a fluoride mouth rinse evaluated in vitro by validated protocols. Braz Dent J 2008;19:9196.

17. Duke SA, Forward GC. The conditions occurring in vivo when brushing with toothpastes. Br Dent J 1982;152:52-54.
18. Argenta RM, Tabchoury CP, Cury JA. A modified $\mathrm{pH}$-cycling model to evaluate fluoride effect on enamel demineralization. Braz Oral Res 2003;17:241-246.

19. Featherstone JD, ten Cate JM, Shariati M, Arends J. Comparison of artificial caries-like lesions by quantitative microradiography and microhardness profiles. Caries Res 1983;17:385-391.

20. Zero DT. In situ caries models. Adv Dent Res 1995;9:214-230.

21. Cury JA, Rebelo MA, Del Bel Cury AA, Derbyshire MT, Tabchoury CP. Biochemical composition and cariogenicity of dental plaque formed in the presence of sucrose or glucose and fructose. Caries Res 2000;34:491-497.

22. Koo H, Cury JA. Soluble calcium/SMFP dentifrice: effect on enamel fluoride uptake and remineralization. Am J Dent 1998;11:173-176.

23. Delbem AC, Carvalho LP, Morihisa RK, Cury JA. Effect of rinsing with water immediately after APF gel application on enamel demineralization in situ. Caries Res 2005;39:258-260.

24. Box GEP, Hunter JS, Hunter WG. Statistics for experimenters: design, innovation, and discovery. 2nd ed. New York: John Wiley \& Sons Inc. 2005.

25. Stephan RM. Changes in hydrogen-ion concentration on tooth surfaces and carious lesion. J Am Dent Assoc 1940;27:718-723.

26. Nordström A, Birkhed D. Preventive effect of high-fluoride dentifrice $(5,000 \mathrm{ppm})$ in caries-active adolescents: a 2-year clinical trial. Caries Res 2010;44:323-331.

27. Marinho VC, Higgins JP, Sheiham A, Logan S. Fluoride toothpastes for preventing dental caries in children and adolescents. Cochrane Data base Syst Rev 2003:CD002278.

28. Fernández $C E$, Tenuta LM, Cury JA. Validation of a cariogenic biofilm model to evaluate the effect of fluoride on enamel and root dentine demineralization. PLoS One 2016;11:e0146478

29. Velo MM, Tabchoury CP, Romão DA, Cury JA. Evaluation of low fluoride toothpaste using primary enamel and a validated $\mathrm{pH}$-cycling model. Int J Paediatr Dent 2016 [Epub Ahead of Print. doi: 10.1111/ipd.12209].

Received February 16, 2016 Accepted May 17, 2016 